\title{
PREFERENSI MASYARAKAT KABUPATEN SUKABUMI DALAM PENGAMBILAN KEPUTUSAN MEMBAYAR ZAKAT
}

\section{SUKABUMI DISTRICT PREFERENCE IN THE DECISION TO PAY ZAKAT}

\author{
N. Kurniawati1a, A. Sukma² \\ 1aAlumni Program Studi Ekonomi Islam Fakultas Ekonomi Islam Universitas Djuanda, Jl. Tol \\ Ciawi No. 1, Kotak Pos 35 Bogor 16770. \\ ${ }^{2}$ Dosen Program Studi Ekonomi Islam Fakultas Ekonomi Islam Universitas Djuanda, Jl. Tol \\ Ciawi No. 1, Kotak Pos 35 Bogor 16770
}

(Diterima oleh Dewan Redaksi: Agustus)

(Dipublikasikan oleh Dewan Redaksi:Desember)

\begin{abstract}
This study aims to determine the characteristics and preferences of society Sukabumi in making decisions to pay zakat. The number of respondents in this study were 204 respondents using purposive sampling technique. Data analysis method used the analysis factors. This study refers to the 14 variables that are assumed to affect the community sukabumi in the decision to pay zakat, namely confidence, communication, family, knowledge, reference group, motivation, interaction, teaching culture, achievements, job, lifestyle, culture implanted, and cultural appropriateness. Confidence greatly influenced the decision to pay zakat through non LPZ. Meanwhile, the factors that influence the decision to pay zakat through the institution of zakat is communication.
\end{abstract}

Keywords: Preferences, Muzakki, Decisions, Zakat.

\section{ABSTRAK}

Penelitian ini bertujuan untuk mengetahui karakteristik masyarakat kabupaten Sukabumi dan preferensi masyarakat dalam mengambil keputusan membayar zakat. Jumlah responden pada penelitian ini sebanyak 204 responden dengan menggunakan teknik Purposive Sampling. Metode analisis data yang digunakan adalah metode analisis faktor. Penelitian ini mengacu pada 14 variabel yang diasumsikan mempengaruhi masyarakat Sukabumi dalam mengambil keputusan membayar zakat yaitu keyakinan, komunikasi, keluarga, pengetahuan, kelompok acuan, motivasi, interaksi, budaya mengajarkan, prestasi, pekerjaan, gaya hidup, budaya ditanamkan, dan kesesuaian budaya. Keyakinan sangat mempengaruhi keputusan membayar zakat melalui non lembaga zakat. Sementara itu, faktor yang mempengaruhi keputusan membayar zakat melalui lembaga zakat adalah komunikasi.

Kata Kunci: Preferensi, Muzakki, Keputusan, Zakat.

Nia Kurniawati. 2015. Preferensi Masyarakat Kabupaten Sukabumi dalam Mengambil Keputusan Membayar Zakat, Jurnal Syarikah 1 (2): 91- 112 


\section{PENDAHULUAN}

Tujuan dari zakat adalah untuk mencegah terjadinya penumpukan dan penimbunan harta pada sekelompok orang. Maka dengan zakat, harta dapat berputar dan tidak menumpuk pada sekelompok orang saja. Hal ini dilakukan dengan cara menyalurkan harta dari orang yang wajib memberi zakat atau muzakki untuk disalurkan kepada penerima zakat yang disebut mustahik.

Zakat juga memiliki tujuan mensejahterakan kehidupan ummat. Pemberian zakat tidak hanya sekedar perpindahan harta dari muzakki kepada mustahik, akan tetapi lebih dari itu yaitu untuk merubah kondisi mustahik. Perubahan kondisi yang dimaksud adalah perubahan dalam kondisi berhak menerima zakat menjadi kondisi yang lebih baik dalam hal ekonomi bahkan menjadi kondisi wajib menunaikan zakat.

Realisasi tujuan tersebut salah satunya dengan cara membayar zakat pada tempat yang tepat dan pengelolaan dana yang tepat. Mashudi (2011: 2) cara pengelolaan dana zakat yang terjadi di Indonesia, biasanya dilakukan oleh individu atau kelompok. Mahmudi dalam Zulfayani (2011: 20) mengatakan masyarakat percaya bahwa pengelolaan zakat efektif dan efesien tentu tidak dilakukan sendiri-sendiri oleh muzakki, tetapi perlu dikelola secara sistematis, terkoordinasi dan terorganisasi dengan baik. Sehingga peran Lembaga Pengelola Zakat (LPZ) sangat penting dalam hal mengumpulkan dana zakat, mengelola dana zakat dan menyalurkan kepada para mustahik zakat. Dana zakat harus dikelola secara amanah dan profesional sehingga tujuan zakat tercapai.

Menurut Badan Amil Zakat Nasional (BAZNAS) jumlah penerimaan dana zakat pada LPZ ditahun 2013 adalah sebesar RP. 2,7 triliun. Data tersebut termasuk data BAZNAS provinsi, kabupaten dan kota serta 18 Lembaga Amil Zakat (LAZ). Menurut Bachmid (2012: 426) data BAZNAS yang mengacu pada hasil kajian Asian
Development Bank (ADB) mengetahui bahwa potensi zakat di Indonesia bisa mencapai Rp.100 triliun per tahun. Penelitian terbaru dari BAZNAS dengan IPB menunjukan potensi zakat di Indonesia mencapai angka Rp. 217 triliun rupiah.

Berdasarkan data tersebut dapat dilihat potensi dana zakat yang sangat besar masih belum tergali secara optimal dengan realisasi penerimaan LPZ belum mencapai $2 \%$ dari potensi zakat Indonesia yang sebesar Rp. 217 triliun rupiah, hal ini bisa dilihat lebih jauh berbasarkan tabel berikut:

Tabel 1. Jumlah Penerimaan Lembaga Zakat di Indonesia Tahun 2011-2013

\begin{tabular}{|c|c|c|c|c|}
\hline \multirow[t]{2}{*}{ No } & \multirow{2}{*}{$\begin{array}{l}\text { Nama } \\
\text { Lembaga }\end{array}$} & \multicolumn{3}{|c|}{$\begin{array}{c}\text { Jumlah Penerimaan } \\
\text { Zakat Masyarakat } \\
\text { (dalam miliaran rupiah) }\end{array}$} \\
\hline & & $\begin{array}{l}\text { Tahun } \\
2011\end{array}$ & $\begin{array}{l}\text { Tahun } \\
2012\end{array}$ & $\begin{array}{l}\text { Tahun } \\
2013\end{array}$ \\
\hline 1 & BAZNAS & 39,9 & 40,3 & 39,5 \\
\hline 2 & $\begin{array}{l}\text { Dompet } \\
\text { Dhuafa }\end{array}$ & 79,9 & 98,2 & 124,3 \\
\hline 3 & PKPU & 25,6 & 35,7 & 50,7 \\
\hline 4 & $\begin{array}{l}\text { Rumah } \\
\text { Zakat }\end{array}$ & 61,1 & 82,5 & 77,7 \\
\hline \multicolumn{2}{|c|}{ Jumlah } & 194,5 & 256,7 & 292.2 \\
\hline
\end{tabular}

Data realisasi penerimaan di atas menunjukan bahwa $98 \%$ masyarakat Indonesia memilih membayar zakat dengan cara yang berbeda. Terlihat dari persentase penerimaan yang tidak tersalurkan melalui lembaga menunjukkan kesenjangan yang begitu besar antara penerimaan dana zakat yang diterima oleh LPZ dengan potensi yang dimiliki. Penghimpunan dana merupakan hal penting dalam zakat agar zakat berjalan secara efektif dan tujuan zakat tercapai.

Kamal ketua BAZNAS Kabupaten sukabumi dalam wawancara dengan Sukabumi Media Center tahun 2009 mengatakan bahwa apabila muzakki yang ada di Kabupaten Sukabumi membayar zakat, maka penerimaan zakat dapat mencapai Rp 540 miliar per tahun. Penerimaan zakat BAZNAS Kabupaten Sukabumi mengalami peningkatan setiap 
tahunnya, akan tetapi peningkatan tersebut belum mencapai 1 persen dari potensi zakat yang ada di Kabupaten Sukabumi. Hal ini terbukti dari data realisasi penerimaan dana zakat dapat dilihat dari tabel berikut:

Tabel 2. Perolehan Zakat BAZNAS Kabupaten Sukabumi

\begin{tabular}{|c|c|c|c|}
\hline Tahun & $\begin{array}{c}\text { Perolehan } \\
\text { Zakat }\end{array}$ & Tahun & $\begin{array}{c}\text { Persentase } \\
\text { Peningkatan }\end{array}$ \\
\hline 2008 & Rp. 2,6 M & $\begin{array}{l}2008- \\
2009\end{array}$ & $7 \%$ \\
\hline 2009 & Rp. 2,8 M & $\begin{array}{l}2009- \\
2010\end{array}$ & $42 \%$ \\
\hline 2010 & Rp. 4 M & $\begin{array}{l}2010- \\
2011\end{array}$ & $22,55 \%$ \\
\hline 2011 & Rp. 4,9 M & $\begin{array}{l}2011- \\
2012\end{array}$ & $32 \%$ \\
\hline 2012 & Rp. 6,5 M & - & - \\
\hline
\end{tabular}

Sumber : BAZNAS Kabupaten Sukabumi

Berdasarkan data di atas membuktikan 99\% masyarakat Kabupaten Sukabumi memilih membayar zakat dengan cara yang berbeda. Persentase dana zakat tersebut menunjukan dana zakat yang ada dimasyarakat belum terserap secara optimal.

Ubaidillah ketua BAZ kota Sukabumi dalam wawancara radar Sukabumi tahun 2013 mengatakan bahwa kesadaran masyarakat kota Sukabumi dalam menyisihkan sebagian hartanya untuk membayar zakat dinilai masih rendah melihat dari wajib zakat kota Sukabumi bisa mencapai 5 miliar per tahun dengan pencapainya hanya 1,5 miliar pada tahun 2012.

\section{MATERI DAN METODE}

Jenis penelitian ini adalah penelitian deskriptif dengan pendekatan penelitian kuantitatif. Data primer yang diperoleh dalam penelitian ini adalah dengan menyebar kuisioner kepada responden yang terpilih untuk dijadikan sampel.

Penelitian ini dilaksanakan di Kabupaten Sukabumi yang memiliki luas wilayah $3.934 \mathrm{Km}^{2}$ dengan jumlah penduduk 2.408.417 jiwa dengan jumlah keluarga sejahtera 693.071 Keluarga sejahtera. Populasi yang digunakan pada penelitian ini adalah seluruh muzakki yang berada di Kabupaten Sukabumi, Sedangkan sampel pada penelitian ini adalah 200 muzakki yang berada di Kabupaten Sukabumi.

Dalam penelitian ini, teknik sampling yang digunakan adalah non probabilitas sampling. Jumlah masyarakat sebagai responden yang diamati sebanyak 200 orang untuk memudahkan dalam analisis dengan asumsi kenormalan, dan pembatasan sampel karena penulis menggunakan purposive sampling. Elemen populasi yang dipilih sebagai sampel dibatasi pada elemen-elemen yang dapat memberikan informasi berdasarkan pertimbangan tersebut Pertimbangan dalam pengambilan sampel adalah sebagai berikut:

1. Responden merupakan muzakki yang membayar zakat baik melalui Badan Amil Zakat, LAZ swasta, atau langsung ke mustahik.

2. Responden mudah ditemui dan bersedia mengisi kuisioner yang diberikan.

3. Penghasilan responden rata-rata (berkisar $\geq$ Rp 3.600.000/bulan), yaitu yang harus memiliki penghasilan atau kekayaan minimal telah mencapai nisab Zakat.

Tehnik analisis data pada penelitian ini menggunankan analisis faktor. Kuisioner menggunakan skala likert sehingga dilakukan uji validitas dan reliabilitas terlebih dahulu. Uji validitas menunjukan sejumlah mana suatu alat pengukuran itu mampu mengukur apa yang diukur. Instrumen yang valid berarti alat ukur yang digunakan untuk mendapat data (mengukur) itu valid. Jadi validitas ingin mengukur apakah pertanyaan dalam kuisioner yang dibuat sudah betul-betul dapat mengukur apa yang diukur (Barna, 2010:81). Valid menunjukan derajat ketepatan antar data yang sesungguhnya terjadi pada objek dengan data yang dikumpulkan peneliti. Apabila suatu alat 
pengukuran telah dinyatakan valid, maka berikutnya adalah pengukuran reliabilitas dari alat .

Reliabilitas adalah mengindikasikan seberapa konsistensi pengukuran yang dilakukan sepanjang waktu atau berbagai pertanyaan. Atau dengan kata lain, reliabilitas mengindikasikan stabilitas dan konsistensi instrumen pengukuran konsep dan membantu untuk melihat ketepatan pengukuran (Nasution dan Usman, 2007: 112).

Analisis faktor adalah sebuah metode peubah ganda yang bertujuan menjelaskan hubungan antara banyak variabel berkorelasi yang sulit diamati menjadi variabel yang sedikit dan berarti secara konseptual dan relatif bebas, yang disebut faktor. Proses analisis faktor mencoba menemukan hubungan (interrelationship) antar sejumlah variabel yang saling independen satu dengan yang lain, sehingga bisa dibuat satu atau beberapa kumpulan variabel yang lebih sedikit dari jumlah variabel awal. Kumpulan variabel disebut faktor, dimana faktor tersebut tetap mencerminkan variabelvariabel aslinya (junaidi, 2006: 41).

\section{HASIL DAN PEMBAHASAN}

Penelitian ini dilakukan dengan membagikan kuisioner kepada 204 responden, dimana responden yang menjawab kuisioner ini adalah masyarakat Kabupaten Sukabumi yang membayar zakat atau disebut muzakki yang memutuskan membayar zakat melalui lembaga zakat dan non lembaga zakat. Dari 204 responden Kabupaten Sukabumi yang diteliti menggambarkan bahwa sebanyak 44,6\% responden memutuskan memilih cara mambayar zakat melalui lembaga dan $55,4 \%$ responden memutuskan membayar zakat melalui non lembaga. Masyarakat kabupaten sukabumi yang membayar zakat melalui lembaga zakat maupun non lembaga zakat dinilai melalui karakteristik berdasarkan demografi, sikap, dan pengetahuan.

\section{Karakteristik Responden Menurut Demografi}

Penelitian ini menilai karakteristik responden berdasarkan demografi yaitu tempat tinggal, usia, status, jumlah anggota keluarga, tingkat pendidikan, jenis pekerjaan, pendapatan dan pengeluaran.

Berdasarkan hasil penelitian karakteristik demografi responden menurut tempat tinggal terdiri dari, pertama, responden yang memilih membayar melalui lembaga zakat lebih banyak dari Cicurug dengan jumlah 23\% responden menurut Kepala Kecamatan Cicurug Agus Gunawan S.Sos., M.Si. Kecamatan Cicurug adalah salah satu kecamatan paling penting bagi Kabupaten Sukabumi, Provinsi Jawa Barat. Sebagai daerah industri, Cicurug adalah penyumbang penghasilan asli daerah (PAD) terbesar bagi Kabupaten Sukabumi.

Kedua, responden yang memilih melalui non lembaga zakat menggambarkan bahwa responden yang memilih membayar melalui non lembaga zakat lebih banyak di Cicurug dengan jumlah 25,6\% responden.

Jenis Kelamin dalam penelitian ini adalah pria dan wanita, dari data 204 responden 130 pria dan 74 wanita sedangkan pria yang memilih membayar zakat melalui lembaga zakat berjumlah $73,6 \%$ responden dan yang memilih membayar zakat melalui non lembaga zakat sebesar $58,4 \%$, kemudian pada responden berjenis kelamin wanita $26,4 \%$ responden memilih membayar zakat melalui lembaga zakat dan $41,6 \%$ responden membayar zakat melalui non lembaga zakat.

Jumlah anggota keluarga dalam penelitian ini adalah jumlah individu yang berada dalam satu keluarga tersebut, seperti ibu dihitung 1 , bapak dihitung 1 , anak dihitung 1 , sehingga jumlah anggota tersebut adalah 3. Responden yang memutuskan membayar zakat melalui lembaga zakat rata-rata dengan jumlah anggota keluarga 4 orang dalam satu keluarga dengan $30,8 \%$ responden yang memilih. Hal sama juga terjadi pada responden yang memilih membayar zakat 
melalui non lembaga zakat dengan jumlah yang memilih sebanyak 39,8\% responden.

Dengan alasan pada jumlah anggota keluarga 4 pengeluaran untuk pendidikan anak, konsumsi keluarga jauh lebih sedikit dibandingkan keluarga yang memiliki anggota keluarga lebih banyak, dengan pendapatan rata-rata muzakki yang cukup besar sehingga memungkinkan untuk membayar zakat. Sama halnya terjadi pada jumlah anggota keluarga 3 dengan 25,4\% responden lembaga zakat dan 18,6\% responden non lembaga zakat, kemudian dengan jumlah anggota keluarga 5 dengan $28,7 \%$ responden $26,7 \%$ responden non lembaga zakat.

Berbeda halnya dengan anggota keluarga yang lebih banyak seperti data di atas yang memiliki anggota keluarga mulai dari 6 anggota keluarga sampai 10 anggota keluarga kemungkinan peluang untuk membayar zakat pada jumlah anggota keluarga yang lebih banyak sangat kecil, terkecuali dengan alasan muzakki tersebut mempunyai aset atau kekayaan yang lebih besar. Pada anggota keluarga dengan jumlah keluarga hanya 1 maka menurut Engel, et. al.,(1994: 204) biasanya pada usia single atau belum menikah mereka cenderung lebih berorientasi pada keinginan terhadap sesuatu sehingga menghabiskan dari sebagian pendapatannya.

Status dalam penelitian ini adalah status yang menggambarkan responden tersebut dengan gambaran belum menikah, menikah, janda dan duda untuk memberikan informasi karakteristik muzakki atau responden yang menunaikan zakat dengan status yang dimilikinya.

Pada tingkat status yang dimiliki responden dengan mengambil keputusan memilih membayar zakat melalui lembaga zakat lebih besar dengan keterangan status menikah sebesar 83,3\% responden, sama halnya dengan pilihan membayar zakat melalui lembaga zakat lebih responden yang memilih lembaga zakat dengan status menikah sebesar 98\%. Menurut Engel, at, al., (1994: 214) pasar secara keseluruhan kebanyakan tetap orang yang sudah menikah. Sehingga karakteristik responden Kabupaten Sukabumi didominasi oleh responden yang sudah menikah.

Melihat data di atas bahwa yang memiliki status belum menikah dengan 1 orang atau hanya 1\% menunjukan bahwa pendapatan yang belum menikah biasanya relatif masih rendah, Menurut Engel, et, al., (1994: 204) biasanya pada usia single atau belum menikah mereka cenderung lebih berorientasi pada keinginan terhadap sesuatu sehingga menghabiskan dari sebagian pendapatannya. Kesadaran untuk membayar zakatpun masih rendah. Responden yang janda maupun duda terkadang pendapatannya lebih kecil dibandingkan dengan ketika status menikah karena mereka kembali hidup sendiri dengan pendapatan sendiri dan memiliki tanggungan biaya kehidupan anak jika memiliki anak, pada status keluarga yang janda maupun duda mereka membawa preferensi dan pola yang dipelajari saat berkeluarga. Sehingga cenderung sedikit yang membayar zakat dengan status janda maupun duda kecuali mereka memiliki profesi pekerjaan tertentu.

Dalam penelitian ini, usia dikelompokan menjadi usia 20-30 tahun, usia 31-40 tahun, usia 41-50 tahun, usia 5160 tahun dan usia lebih dari 60 tahun. Responden yang membayar zakat melalui lembaga zakat memiliki usia lebih tinggi adalah 31 sampai dengan 40 tahun dengan jumlah $30,8 \%$ responden hal sama juga terjadi pada pilihan membayar zakat melalui non lembaga zakat dengan yang lebih tinggi dengan usia 31 sampai dengan 40 tahun dengan jumlah respoden lebih banyak yaitu sebesar 29,3\% responden. Hal ini dikarenakan pada usia tersebut diberikan kepercayaan untuk melakukan pengambilan keputusan, pada usia tersebut juga merupakan kelompok usia dengan produktifitas lebih tinggi dibandingkan kelompok usia lain. Dan yang paling sedikit adalah kelompok usia lebih dari 60 tahun yaitu sebanyak 2,2\% responden pada pemilihan zakat melalui lembaga zakat dan 
$0,8 \%$ responden yang memilih membayar zakat melalui lembaga karena usia ini adalah usia pensiun sehingga kebanyakan pada kolompok usia ini cenderung orang hanya menikmati hasil usaha yang telah didapat dan menyerahkan setiap keputusan kepada yang lebih muda dan usia tersebut hanya bersifat mengontrol.

Jenis Pekerjaan dalam penelitian ini adalah jenis pekerjaan yang dimiliki responden dengan berbagai profesi kerja sebagai berikut Pegawai Negeri Sipil (PNS), Karyawan Swasta, Petani, Pedagang dan Lainnya. Dalam pilihan lainnya responden diminta untuk menyebutkan jenis pekerjaan lainnya yang tidak terdapat pada pilihan.

Jumlah pekerjaan yang memilih membayar zakat melalui lembaga zakat adalah Pegawai Negeri Sipil (PNS) dengan jumlah responden sebanyak 59,4\%. karena memiliki tingkat pendidikan yang tinggi sehingga mempengaruhi pola pikir responden.

Adapun responden yang memilih membayar zakat melalui non lembaga zakat lebih banyak pada profesi kerja sebagai pedagang sebanyak $37,2 \%$ responden dengan tingkat pendidikan tertinggi adalah SMA sederajat, sehingga berpengaruh terhadap posisi pekerjaan dan pola pikir responden itu sendiri.

Pendidikan dalam penelitian ini adalah jenjang pendidikan terakhir yang sudah ditempuh responden, tingkat pendidikan terakhir yang dimiliki respoden dalam penelitian ini mulai dari SD, SMP, SMA, D3, S1 sampai S2. Hal ini menunjukan bahwa tingkat pendidikan terakhir responden berhubungan dengan pengambilan keputusan responden dalam membayar zakat. Rata-rata jumlah responden yang memilih pada lembaga zakat adalah perguruan tinggi S1 dengan jumlah 56\% responden. Tingkat pendidikan terakhir yang memilih membayar zakat melalui lembaga didominasi tingkat perguruan tinggi S1 sampai S2.

Sedangkan responden yang memilih membayar zakat melalui non lembaga zakat tingkat pendidikan tertinggi adalah SMA sederajat dengan jumlah responden 52,3\%. Hal ini membuktikan bahwa tingkat pendidikan terakhir yang memilih membayar melalui lembaga hanya tingkat SMA/Sederajat dibandingkan dengan yang membayar zakat melalui lembaga zakat dengan tingkat pendidikan lebih tinggi yaitu S1.

Pendapatan responden adalah pendapatan yang dihasilkan setiap bulannya oleh responden penghasilan pada penelitian ini dimulai dari pendapatan sudah mencapai nisab zakat dengan nisab zakat harga emas pada saat penelitian berlangsung yaitu Rp 500.000 atau kurang lebih sekitar $\mathrm{Rp} 3.600 .000$ perbulan atau lebih.

Dilihat dari pendapatan responden yang memilih membayar zakat melalui lembaga zakat maupun non lembaga zakat adalah responden dengan rata-rata pendapatan Rp 3.600.000 sampai dengan Rp 5.600.000 dengan jumlah responden sebanyak $87 \%$ yang memilih melalui lembaga zakat dan melalui non lembaga zakat sebayak 79\% responden.

Pengeluaran pada penelitian ini adalah pengeluaran yang dikeluarkan oleh responden setiap bulannya dengan pendapatan yang diterima oleh responden. Pengeluaran responden yang memilih membayar zakat melalui lembaga zakat lebih banyak dengan pengeluaran tertinggi Rp 3.000.001-Rp 4.000.000 dengan jumlah $29,7 \%$ responden, kedua pengeluaran $\mathrm{Rp}$ 4.000.001-Rp 5.000.000 dengan jumlah $25,4 \%$ responden, yang ketiga $\mathrm{Rp}$ 2.000.001-Rp 3.000.000 dengan jumlah $22 \%$ responden, yang keempat adalah $\mathrm{Rp}$ 1.000.000-Rp 2.000.000 dengan jumlah $14,2 \%$ responden dan yang kelima adalah lebih dari Rp 5000.001 sebanyak 9\% responden dengan rata-rata pendapatan $\mathrm{Rp}$ 3.600.000-Rp 5.600.000.

Sedangkan pada pemilihan non lembaga zakat responden lebih banyak pada pengeluaran tertinggi pertama adalah Rp 2.000.001-Rp 3.000.000 dengan jumlah $38,9 \%$ responden, yang kedua adalah $\mathrm{Rp}$ 
1.000.000- Rp 2.000.000 dengan jumlah $31,8 \%$ responden, yang ketiga adalah $\mathrm{Rp}$ 4.000.001-Rp 5.000 .000 dengan jumlah $12,4 \%$ responden yang keempat $\mathrm{Rp}$ 3.000.001- Rp 4.000.000 dengan jumlah 13 $11,5 \%$ responden, yang kelima adalah lebih dari $\mathrm{Rp} 5.000 .0000$ dengan jumlah 5,4\% responden.

Karakteristik Responden berdasarkan Sikap.

Keluarga dalam penelitian ini adalah keluarga dari responden yaitu orang tua, saudara, kakak atau adik yang mempengaruhi keputusan responden dalam membayar zakat sehingga sikap yang responden ambil karena mengikuti yang dilakukan oleh keluarga.

Sebanyak 69,3\% responden pada pilihan cara membayar zakat melalui lembaga dan $72 \%$ responden pada pilihan membayar zakat melalui non lembaga zakat dipengaruhi keluarga dalam memutuskan pembayaran zakat. Hal ini menggambarkan bahwa keluarga berpengaruh besar terhadap pembentukan sikap responden dalam mengambil keputusan membayar zakat.

Pemahaman dan pembelajaran dalam penelitian ini adalah pembelajaran dan pemahaman tentang zakat yang didapat oleh responden dari keluarga responden atau pendidikan lain. $96 \%$ responden menjawab Ya dari yang memilih membayar melalui lembaga zakat dan 93\% responden yang menjawab Ya dari yang membayar zakat melalui non lembaga zakat atas pertanyaan pemahaman dan pembelajaran mempengaruhi cara membayar zakat. Hal ini membuktikan bahwa perlakuan, pendidikan, pemahaman yang diterapkan kepada responden menentukan sikap dalam memilih cara membayar zakat.

Lingkungan dalam penelitian ini adalah lingkungan yang berada disekitar responden tetangga, teman dan lingkungan tempat bekerja. Sehingga apakah lingkungan tersebut dapat mempengaruhi keputusan responden dalam menentukan sikap memilih cara membayar zakat. Jawaban responden Ya dengan 73 responden atau $80,3 \%$ yang memilih membayar zakat melalui lembaga dan 89 responden atau $78,7 \%$ responden yang memilih membayar zakat melalui non lembaga. Hal ini membuktikan bahwa teman ataupun lingkungan tempat bekerja menjadi masukan dan pertimbangan bagi muzakki dalam memutuskan membayar zakat

Dari pengaruh keluarga dan lingkungan yang dijelaskan di atas dapat dibandingkan bahwa sikap responden dalam memilih membayar zakat melalui lembaga zakat ditentukan oleh lingkungan dengan jumlah persentase sebesar 80,3\%, dan sikap responden yang memilih membayar zakat melalui non lembaga zakat ditentukan juga oleh lingkungan dengan nilai persentase sebesar 78,7\%.

Keyakinan dalam penelitian ini adalah keyakinan responden terhadap cara yang telah dipilih, hal ini berhubungan dengan tingkat perasaan responden terhadap pilihannya dengan menuliskan alasan dari responden.

Responden yang membayar zakat melalui lembaga zakat maupun melalui non lembaga zakat mejawab Ya dengan keyakinan terhadap pilihan cara membayar zakat yang telah dipilih dengan jumlah $99,9 \%$ responden dengan $1 \%$ responden memilih tidak pada responden yang membayar zakat melalui lembaga dengan alasan sudah tepat sasaran, penyalurannya tepat dan dapat dipercaya, karena melalui lembaga yang mengelolanya, lebih terkoordinir, dan karena sudah ditegaskan dalam ayat 60 Qs. At Taubah.

Adapun responden yang memilih membayar dengan cara membayar melalui non lembaga zakat adalah sebanyak 97,4\% responden dengan alasan karena sudah terbiasa dengan cara yang dipilih, menemtramkan hati, karena sudah tepat sasaran, karena sesuai dengan Al-Quran, langsung diterima oleh yang berhak, masih banyak dilingkungan yang membutuhkan. Hal ini menunjukan bahwa sikap responden dalam memilih cara membayar zakat ditentukan oleh keyakinan responden 
terhadap pilihannya dengan alasan dan juga terlihat dari alasan tersebut bahwa responden yang membayar zakat melalui non lembaga memiliki pengetahuan zakat lebih tinggi dibandingkan dengan responden yang memilih membayar zakat melalui non lembaga zakat.

Kepuasan dan kenyamanan dalam penelitian ini adalah perasaan puas dan nyaman terhadap pelayanan, transparansi, kemudahan, untuk menunaikan kewajiban yang dimiliki responden terhadap cara membayar zakat yang telah dipilih responden. Responden yang membayar zakat melalui lembaga zakat menyataan Ya dengan perasaan puas dan nyaman terhadap cara membayar zakat yang dipilih dengan 97,8\% responden dengan alasan zakat lebih terkoordinir, karena ada petugas yang mengelolanya, karena pada badan yang resmi, percaya pada pengelola zakat, karena percaya dan yakin pada BAZNAS, lebih simpel, dan transparan.

Adapun responden yang memilih membayar dengan cara melalui non lembaga zakat yakni sebesar 73,4\% responden. Alasan yang diutarakan karena ada ijab dan qabulnya, bisa langsung memberi pada yang berhak, lebih jelas untuk sikapnya dan merasa puas, karena responden merasa lebih tahu siapa yang berhak menerima zakat yang berada dilingkungannya, karena merasa sudah melaksanakan perintah Allah, karena bisa memberi disekitar rumah.

Dari alasan yang dikemukakan oleh responden yang membayar zakat melalui lembaga zakat terlihat bahwa kepuasan karena sudah memberi amanah kepada lembaga zakat menggambarkan bahwa tingkat kepercayaan terhadap lembaga cukup baik. Adapun responden yang memilih membayar zakat melalui non lembaga zakat dengan alasan karena ketidak percayaan terhadap lembaga sangat tinggi dan informasi mengenai lembaga zakat dan pengelolaan didalamnya pun tidak banyak diketahui responden. Hal ini menunjukan bahwa sikap responden dalam memilih cara membayar zakat ditentukan kepuasan dan kenyamanan responden.

Konsistensi dalam penelitian ini adalah ingin melihat tingkat kesetiaan atau konsistensi responden terhadap pilihan cara membayar zakat yang telah dipilih oleh responden, dengan menanyakan apakah setiap kali membayar zakat selalu dengan cara yang sama, $78 \%$ responden melakukan cara yang sama setiap membayar zakat dengan alasan karena kebiasaan, agar istiqamah dalam syariat Islam, petugas yang mengelola sudah terpercaya, tidak ada unsur korupsi, dan dipotong dari gaji bulanan. Dan 22\% menjawab tidak dengan alasan tidak responden selalu membayar melalui lembaga zakat.

Sedangkan responden yang memilih membayar zakat tidak melalui lembaga sebesar 78,7\% responden dengan alasan mengikuti cara dilingkungan, karena tidak ada lembaga pengelola zakat dilingkungan rumah, tradisi, lebih mudah, dan sudah terbiasa. Yang menjawab Tidak 31,3\% responden dengan alasan kadang-kadang sama kadang-kadang tidak. Dalam hal ini unsur kepercayaan terhadap lembaga sangat menentukan sikap apakah responden tersebut pemilihan cara membayar zakat.

\section{Karakteristik Responden Berdasarkan Pengetahuan Tentang Zakat.}

Karakteristik

responden

berdasarkan pengetahuan tentang zakat ini adalah untuk mengetahui pengetahuan responden tentang zakat, dalam penelitian ini yang termasuk pengetahuan zakat adalah informasi yang didapat oleh responden tentang zakat, macam-macam zakat yang dibayar oleh responden, besaran zakat yang dikeluarkan responden setiap bulannya, perhitungan zakat, orang yang berhak menerima zakat, syarat-syarat harta yang wajib dizakati, tujuan zakat, dan cara pengelolaan zakat.

Informasi tentang macam-macam zakat yang biasa dibayar dalam penelitian ini adalah macam-macam zakat seperti zakat profesi, zakat penghasilan, zakat perdagangan, zakat pertanian, zakat 
tanaman dan buah-buahan, zakat peternakan, zakat harta temuan dan zakat fitrah. Dalam macam-macam zakat disini responden diberikan kesempatan untuk memilih lebih dari satu jawaban terhadap zakat yang biasa dibayar responden, informasi macam-macam zakat ini juga dapat menggambarkan pengetahuan tentang macam-macam zakat yang diketahui oleh responden.

Responden lebih banyak membayar zakat profesi dengan jumlah 83,2\% responden dengan memilih membayar zakat dengan melalui lembaga zakat dan responden non lembaga zakat lebih banyak dengan pilihan zakat lainnya yaitu sebanyak $37,2 \%$ responden. Hal ini menunjukan bahwa tingkat pekerjaan responden dan tingkat pendidikan terakhir responden mempengaruhi pengetahuan responden tentang zakat ditunjukkan pada responden yang memilih membayar zakat melalui lembaga zakat didominasi oleh pekerjaan PNS dengan tingkat pendidikan tertinggi S1 dan zakat yang biasa dibayarpun adalah zakat profesi. Adapun pada responden yang memilih membayar zakat melalui non lembaga zakat dengan jenis pekerjaan yang paling tinggi adalah pedagang dengan tingkat pendidikan SMA sederajat menyebutkan zakat yang biasa dibayarkan adalah zakat perdagangan.

Disini artinya bahwa responden yang membayar zakat melalui lembaga adalah memiliki pengetahuan yang cukup baik tentang zakat dan macam-macam zakatnya sedangkan responden yang memilih membayar zakat melalui non lembaga zakat memiliki pengetahuan yang kurang baik tentang zakat dan macammacam yang biasa dibayar.

Pengeluaran zakat perbulan dalam penelitian ini adalah pengeluaran yang biasa dikeluarkan oleh responden setiap bulannya, dalam pengeluaran zakat perbulan merupakan bentuk informasi yang didapat dari responden kisaran berapa zakat yang biasa dibayar oleh responden. Rata-rata responden yang membayar zakat melalui lembaga zakat adalah kisaran $\mathrm{Rp}$
100.000 sampai dengan Rp 200.000 per bulan dengan jumlah responden $41 \%$ responden. Sama halnya responden yang membayar zakat melalui non lembaga zakat memiliki kisaran pengeluaran zakat sebesar Rp 100.000 sampai dengan Rp 200.000 per bulan dengan jumlah 34,6\% responden atau sekitar Rp 1000.000 sampai Rp 2.000.000 pertahun sedangkan tingkat yang kedua adalah kurang dari Rp 100.000 perbulan dengan jumlah responden yang membayar zakat melalui lembaga sebanyak 40,7\% sedangkan melalui non lembaga sebesar $43,6 \%$ responden. Ketiga kisaran Rp 200.001-Rp 300.000 dengan jumlah responden $14,3 \%$ yang membayar zakat melalui lembaga dan 9,7\% responden yang membayar zakat melalui non lembaga zakat. Sedangkan yang yang keempat $\mathrm{Rp}$ 300.001-Rp 400.000 berjumlah 2,3\% responden yang memilih membayar zakat melalui lembaga zakat dan 15\% responden yang membayar zakat melalui non lembaga. Yang kelima Rp 400.001-Rp 500.000 responden berjumlah $0 \%$ artinya responden yang memilih membayar zakat melalui lembaga zakat tidak ada yang memilih dalam penelitian ini sedangkan $7 \%$ responden atau yang memilih membayar zakat melalui non lembaga zakat. Yang kelima lebih dari Rp 500.000 dengan jumlah responden hanya $1 \%$ dan $2,7 \%$ responden atau yang memilih membayar zakat non melalui lembaga. Melihat pengeluaran zakat responden setiap bulannya menunjukan bahwa potensi lebih tinggi berada pada responden yang memilih membayar zakat melalui non lembaga zakat.

Pengetahuan mengenai pendapat responden perlu atau tidak membayar zakat melalui lembaga zakat menurut masing-masing responden yang membayar melalui lembaga maupun lembaga zakat dengan menyebutkan alasan masingmasing. Dari hasil penelitian menunjukan 91\% dari responden yang memilih membayar zakat melalui lembaga zakat menyatakan perlu membayar zakat melalui lembaga zakat dengan alasan agar dikelola 
dengan baik, lebih terkoordinir, agar pendistribusiannya merata, lebih terprogram, untuk sentralisasi zakat, agar tersalurkan pada mustahik, dan lebih aman. Dan yang menjawab tidak 18\% responden dengan alasan belum yakin dengan lembaga zakat.

Begitupun responden yang membayar zakat melalui non lembaga zakat menyatakan tidak perlu membayar zakat melalui lembaga yaitu sebanyak $76,2 \%$ respoden dengan alasan kurang percaya dengan lembaga zakat dan masih banyak mustahik yang berada dilingkungan yang lebih membutuhkan karena khawatir ada zakat yang tidak tersalurkan. Selain itu responden merasa repot dan khawatir zakat tidak sampai pada orang yang tepat, serta merasa lembaga zakat tidak transparan dan terpercaya. Dan sebanyak 23,8\% memiliki alasan karena dilingkungan rumahnya tidak ada lembaga zakat dan jarak tempuh lembaga zakat yang cukup jauh.

Informasi zakat dalam penelitian ini untuk mengetahui dari mana responden mengetahui informasi mengenai zakat, melalui media cetak, melalui iklan di televisi, melalui info dari keluarga, melalui info dari tetangga dan lainnya, lainnya dalam penelitian ini responden dapat menyebutkan dari mana ia mendapat informasi mengenai zakat dan dapat memilih lebih dari satu pilhan jawaban.

Pilihan terbesar adalah 30,7\% rasponden yang memilih membayar zakat melalui lembaga pengelola zakat mendapat informasi dari lainnya yaitu melalui sosialisasi BAZNAS, dinas, tempat bekerja, organisasi. Hal samapun terjadi pada pemilihan non lembaga zakat didominasi oleh responden yang memilih informasi lainnya sebesar $27 \%$ responden menyebutkan mendapat informasi melalui Al Quran dan hadist, guru, ustdaz, pengajian, majlis ta'lim, belajar, alim ulama.

Perhitungan zakat dalam penelitian ini adalah untuk mengetahui pengetahuan responden tentang pengetahuan perhitungan zakat terhadap zakat yang telah dibayar responden.

Rata-rata responden telah mengetahui cara perhitungan zakat terbukti dari hasil penelitian menunjukkan bahwa 100\% responden yang memilih membayar zakat dilembaga zakat menyatakan mengetahui cara perhitungan zakat dengan rata-rata jawaban yang disebutkan oleh responden adalah 2,5\% dari penghasilan.

Responden yang membayar zakat melalui non lembaga mengetahui cara perhitungan zakat dengan jumlah 81\% responden dengan rata-rata jawaban yang disebut responden adalah 2,5\% dari pendapatan, $10 \%$ atau $5 \%$ dari zakat pertanian, setiap dapat penghasilan dikeluarkan 2,5\%. Hal ini bahwa pengetahuan menentukan cara membayar zakat yang akan dipilih responden. Pengetahuan tentang perhitungan responden yang membayar zakat melalui lembaga zakat lebih besar dibandingkan dengan pengetahuan responden yang membayar zakat melalui non lembaga zakat.

Pengetahuan tentang orang-orang yang wajib menerima zakat dalam penelitian ini adalah untuk mengetahui apakah responden mengetahui orang-orang yang berhak menerima zakat, dengan harapan jawaban 8 asnaf yang telah ditentukan dalam Al Quran surat At Taubah ayat 60 yaitu fakir, miskin, ibnu sabil, fisabilillah, gharimin, amil, riqob, dan mualaf. 99\% responden yang memilih membayar zakat melalui lembaga zakat menjawab ya dengan pengetahuan orang yang berhak menerima zakat dengan masing-masing menyebutkan jawabanya yaitu 8 asnaf, fakir, miskin, fisabilillah, yatim, gharimin, ibnu sabil, jompo.

Responden yang memilih membayar zakat melalui non lembaga memiliki jawaban yang sama yaitu sebesar 93,8\% menjawab ya terhadap pengetahuan tentang orang-orang yang berhak menerima zakat dengan masing-masing menyebutkan jawabannya yaitu, fakir, miskin, jompo, janda tua, anak yatim, fisabilillah, guru 
mengaji, dhuafa, masjid, mualaf. Dapat disimpulkan bahwa pengetahuan tentang orang-orang yang berhak wajib menerima zakat lebih banyak yang mengetahui 8 asnaf adalah responden yang membayar zakat melalui lembaga. Hal tersebut menyatakan bahwa pengetahuan terhadap orang-orang yang berhak menerima zakat mempengaruhi cara membayar zakat yang dipilih dengan responden menyebutkan jawaban dengan berbeda-beda.

Pengetahuan tentang syarat-syarat harta yang wajib dizakati dalam penelitian ini adalah pengetahuan tentang batasan syarat-syarat yang sudah mencapai wajib dizakati, dengan harapan jawaban sudah sampai nisab dan haul dari harta tersebut. Jawaban responden terhadap pengetahuan tentang syarat-syarat harta yang wajib dizakati rata-rata responden memilih jawaban ya dengan persentase $92,4 \%$ pada responden yang memilih membayar zakat melalui lembaga zakat dengan $85 \%$ pada responden yang memilih zakat melalui non lembaga zakat dengan rata-rata responden menyebutkan jawaban tersebut yaitu sudah sampai nisab dan haul.

Pengetahuan tentang tujuan zakat dalam penelitian ini adalah untuk mengetahui apakah responden mengetahui tujuan zakat terhadap responden yang memilih membayar zakat melalui lembaga zakat dan melalui non lembaga zakat. Jawaban responden terhadap tujuan zakat adalah ya dengan masing-masing persentase yang berbeda lembaga zakat berdasarkan pengetahuan tentang pengelolaan zakat $97,8 \%$ responden pada responden yang memilih membayar zakat melalui lembaga dengan menyebutkan jawaban untuk membersihkan harta, untuk pemerataan, mensejahterakan fakir miskin, menolong sesama, menunaikan rukun Islam yang ke 4.

Kemudian 95\% responden pada responden yang membayar zakat melalui non lembaga zakat dengan menyebutkan jawaban untuk membersihkan harta, kewajiban agama, untuk memberi kepada yang membutuhkan, dan menunaikan rukun Islam yang ke 4 .

Pengetahuan tentang pengelolaan zakat dalam penelitian ini adalah untuk mengetahui pengetahuan responden tentang pengelolaan zakat yang diketahui oleh responden. $67 \%$ responden responden yang membayar zakat melalui lembaga menjawab ya terhadap pengetahuan membayar zakat dengan menyebutkan jawabannya yaitu dikelola oleh amilin BAZNAS, 1. menunaikan melalui amilin 2. Dikelola oleh amilin 3 didistribusikan kepada 8 asnaf dengan produktif maupun konsumtif. Sedangkan 51,4\% responden pada jawaban responden yang memilih membayar zakat melalui non lembaga dengan jawaban yang disebutkan responden yaitu dikelola oleh amil.

\section{Uji Reliabilitas dan Validitas}

Uji reliabilitas dari masing-masing faktor menggunakan Crombach's Alpha. Kuisioner dinyatakan reliabel jika mempunyai nilai koefisien alpha yang lebih besar $>0,5$. Dari hasil pengujian maka semua instrumen dikatakan reliabel karena nilai koefisien Cronbach Alpha diperoleh lebih besar dari $0,5(\alpha \geq 0,5)$ yaitu sebesar 0,764 (Faktor Budaya), 0,785 (Faktor Sosial), 0,695 (Faktor Pribadi), 0,797 (Faktor Psikologi). Dengan demikian instrumen yang digunakan dalam penelitian ini cukup handal dalam mengukur persepsi responden terhadap variabel yang diteliti dan dapat dilanjutkan ke tahap selanjutnya.

Uji validitas dilakukan untuk menguji kuisioner layak dan digunakan sebagai intrumen penelitian. Valid berarti intrumen tersebut dapat digunakan untuk mengukur apa yang seharusnya diukur. Kriteria dari validitas yaitu bila koefisien korelasi masing-masing peryataan dengan nilai Correected Item Total Correlation lebih besar atau sama dengan nilai $r$ tabel. Maka dinyatakan valid (nilai $r$ tabel dengan responden 30 orang adalah 0,361 ).

Dari hasil pengelolahan data bahwa koefisien korelasi dari 50 butir pertanyaan yang ada, dikatakan 26 yang valid dengan skor $>0,361$ dan dapat diolah lebih lanjut. 
Metode analisis data yang digunakan adalah metode analisis faktor dengan bantuan software SPSS Versi 20 for Windows. Untuk lebih jelasnya akan dijelaskan tahapan demi tahapannya.

\section{Analisis Faktor Muzakki yang Membayar melalui Lembaga Zakat}

Analisis faktor lembaga zakat dalam penelitian ini adalah untuk mengetahui faktor apa saja yang mempengaruhi preferensi masyarakat dalam nengambil keputusan membayar zakat .

Langkah pertama dari pengolahan analisis faktor adalah menilai variabel yang dianggap layak dan telah diuji validitasnya untuk dimasukan kedalam analisis selanjutnya. Dari hasil pengelolahan data dengan program SPSS 20 diperoleh output hasil pengelolahan yaitu dua nilai KMO yaitu KMO untuk lembaga zakat dan KMO untuk non lembaga zakat.

Dari hasil pengolahan data diperoleh angka Kaiser mayer Olkin Measure of Sampling Adequacy (KMO-MSA) sebesar 0,671 lembaga zakat dan 0,650 untuk non lembaga zakat, hasil ini termasuk pada hasil yang baik mengingat angka ini sudah diatas 0,5. Nilai Bartlett's Test of Sphericity mempunyai nilai 392.081 pada lembaga zakat dan 451.541 pada non lembaga zakat dengan nilai signifikasi 0,000 . Nilai ini berarti bahwa faktor pembentuk variabel sudah cukup dan bisa dianalisis lebih lanjut.

Proses Ektraksi merupakan proses inti dari analisis faktor, yaitu melakukan ektraksi terhadap sekumpulan variabel yang telah lolos pada uji validitas sebelumnya, sehingga terbentuk satu atau lebih faktor. Metode ekstraksi principal Componennt Analisis (PCA), dengan tingkat Eigenvalues over $=1$, yang artinya dengan angka eigenvalues dibawah 1 akan dikeluarkan. Dari ektraksi ini didapat tabel Communaliti tabel Total Variance Explained, tabel Component Matrix sebagai berikut:
Tabel 3. Nilai Communalities

\begin{tabular}{lcc} 
& Initial & Extraction \\
\hline Budaya ditanamkan & 1.000 & .660 \\
Budaya & & .504 \\
mengajarkan & 1.000 & \\
Budaya & & .848 \\
menyesuaikan & 1.000 & .601 \\
Pekerjaan & 1.000 & .495 \\
Prestasi & 1.000 & .740 \\
Interaksi & 1.000 & .708 \\
Kepemilikan & 1.000 & .525 \\
Gaya.hidup & 1.000 & .684 \\
Keluarga & 1.000 & .815 \\
Komunikasi & 1.000 & .707 \\
Kelompok.acuan & 1.000 & .609 \\
Pengetahuan & 1.000 & .739 \\
Motivasi & 1.000 & .774 \\
Keyakinan & 1.000 & \\
\hline Extraction Method: Principal Component \\
Analysis.
\end{tabular}

Nilai initial merupakan varian variabel sebelum dilakukan ekstrak. Semua nilai initial bernilai 1, hal ini berarti bahwa sebelum dilakukan ekstraksi variabel tersebut $100 \%$ membentuk faktor tersebut, karena faktor sebelumnya dilakukan ekstraksi adalah sama dengan variabel. Nilai extraction menggambarkan besar persentase varian sesuai variabel yang dapat dijelaskan oleh faktor yang akan terbentuk. Untuk variabel budaya yang menyesuaikan, mempunyai nilai extraction tertinggi yaitu sebesar 0,848 . Hal ini berarti $84,4 \%$ varian variabel budaya menyesuaikan akan terbentuk. Kemudian untuk variabel budaya ditanamkan 66\%, budaya megajarkan $50,4 \%$, pekerjaan $60 \%$, interaksi $74 \%$ kepemilikan $70,8 \%$, gaya hidup 52,5\% keluarga 68,4\%, komunikasi 81,5\%, kelompok acuan 70,7\%, pengetahuan $60,9 \%$, motivasi $73,9 \%$, keyakinan $77,4 \%$ dan variabel prestasi mempunyai nilai extraction terendah 0,495 . Hal ini berarti $49,5 \%$ varian dari variabel gaya hidup dapat dijelaskan oleh faktor yang akan terbentuk dan variabel semakin besar nilai communalities menunjukan semakin kuat hubungan dengan faktor yang nantinya akan terbentuk. Selanjutnya 
berdasarkan pengolahan data SPSS 20 didapat hasil bahwa 14 variabel yang digunakan dalam penelitian ini akan dikelompokan dalam 5 faktor.

Berdasarkan output total variance eksplained dapat diketahui bahwa:

a. Faktor pertama yang mempunyai eigenvalue sebesar $=3,844$, varian sebesar $27,457 \%$

b. Faktor kedua mempunyai nilai eigenvalue sebesar $=1.797$, varian sebesar $12,833 \%$

c. Faktor ketiga mempunyai nilai eigenvalue sebesar $=1.459$, varian sebesar $10,419 \%$

d. Faktor keempat mempunyai nilai eigenvalue sebesar $=1.208$, varian sebesar $8,626 \%$

e. Faktor kelima mempunyai nilai eigenvalue sebesar $=1.101$, varian sebesar 7,862\%

Hasil tersebut menunjukan bahwa faktor 1 mampu menjelaskan seluruh varian sebesar 27,457\%, faktor 2 menjelaskan seluruh varian sebesar $12,833 \%$, faktor 3 menjelaskan seluruh varian sebesar 10,419\%, faktor 4 menjelaskan seluruh varian sebesar 8,626\%, dan faktor 5 menjelaskan seluruh varian sebesar 7,862\%. Adapun berdasarkan kumulatif seluruh faktor dapat menjelaskan varian sebesar 67,197\%.

Setelah didapat 5 faktor adalah jumlah yang paling optimal, analisis selanjutnya dilakukan pada component matrix yang menunjukan distribusi 14 variabel pada 5 faktor yang terbentuk. Angka-angka pada component matrix merupakan factor of loading yang menunjukan besar kolerasi antara suatu variabel dengan faktor pertama, kedua, ketiga, keempat dan kelima. Proses penentu variabel asal kedalam faktor dilakukan dengan membandingkan besar kolerasi tiap baris yang didasarkan pada angka mutlak factor of loading yang diberikan setiap variabel terhadap masing-masing faktor.

Berdasarkan hasil penelitian untuk component matrix, masih ada beberapa variabel yang tidak terlihat perbedaan nyata pada nilai loading factor, sehingga sulit untuk menentukan variabel tersebut termasuk faktor yang mana. Hal ini terlihat dari masih ada nilai loading factor yang di bawah 0,5, yaitu pada variabel gaya hidup. Padahal syarat suatu variabel masuk kedalam suatu faktor, nilai loading factor harus di atas 0,5. Untuk melihat perbedaan yang nyata pada nilai loading factor dari setiap variabel, maka harus dilakukan proses rotasi. Rotasi dalam penelitian ini adalah rotasi dengan metode Varimax, yang bertujuan untuk memperbesar nilai loading factor yang dulunya memang sudah besar dan memperkecil nilai loading factor yang dulunya memang sudah kecil, sehingga diperoleh distribusi loading factor yang lebih jelas dan nyata.

Setelah dilakukan rotasi, maka dapat dengan mudah menentukan variabelvariabel mana yang akan masuk kelima faktor tersebut. Dari rotated komponen matrix kita melihat bahwa variabel yang termasuk dalam component 1 yaitu variabel keyakinan, komunikasi, keluarga, pengetahuan, kelompok acuan, dan motivasi. Dengan nilai factor of loading masing-masing variabel sebesar 0,850, $0,842,0,752,0,595,0,540$, dan 0,534. Hal ini berarti, bahwa variabel tersebut mempunyai kolerasi yang tinggi terhadap faktor 1, kemudian untuk component 2 yaitu variabel interaksi, budaya mengajarkan, prestasi, dan pekerjaan dengan nilai factor of loading masing-masing variabel sebesar $0,732,0,678,0,574$, dan 0,568, kemudian untuk component 3 yaitu gaya hidup dengan nilai factor of loading sebesar 0,534, kemudian untuk component 4 yaitu budaya yang ditanamkan dengan nilai factor of loading sebesar 0,808 dan untuk component 5 yaitu budaya menyesuaikan dengan nilai factor of loading sebesar 0,883 .

Hasil analisis faktor adalah 14 variabel yang diteliti melalui analisis faktor dengan metode ekstraksi principle component analysis yang direduksi menjadi 5 faktor dimana variabel-variabel keyakinan, komunikasi, keluarga, pengetahuan, kelompok acuan, dan 
motivasi, yaitu faktor 1, interaksi, prestasi, dan pekerjaan yaitu faktor 2 , pekerjaan adalah faktor 3 , budaya mengajarkan yaitu faktor 4 , dan budaya menyesuaikan yaitu faktor 5 .

Faktor pertama didapatkan persamaan matematis sebagai berikut: $\mathrm{F}_{1}=0,850$ Keyakinan $+0,842$ Komunikasi + 0,752 Keluarga $+0,595$ Pengetahuan 2 $+0,540$ Kelompok acuan $+0,534$ Motivasi

Faktor pertama ini memiliki eigenvalue sebesar 3,844, sehingga dapat disimpulkan bahwa ini merupakan faktor yang paling mempengaruhi keputusan membayar zakat melalui lembaga zakat, faktor 1 ini dapat mempengaruhi keragaman data sebesar $27.457 \%$.

Keyakinan adalah keadaan dimana seseorang meyakini terhadap keputusan yang dipilih, dari hasil kuisioner memperlihatkan bahwa $85 \%$ responden mengambil keputusan atas dasar keyakinan, faktor ini merupakan faktor yang paling mempengaruhi sehingga menjadi daya tarik utama pengambilan keputusan membayar zakat melalui lembaga zakat. Hal ini dapat diartikan bahwa ada sekelompok muzakki yang membayar zakat melalui lembaga zakat adalah orang yang meyakini terhadap setiap keputusan yang dipilih, yang selalu menjadikan pengalaman sebuah pembelajaran dalam meyakinkan keputusan yang dipilih, orang yang tidak pernah memihak pada situasi apapun, sehingga dengan keyakinan yang dimiliki dan pengalaman yang selalu dijadikan pembelajaran sehingga muzakki ini memutuskan membayar zakat melalui lembaga zakat.

Komunikasi dalam penelitian ini adalah komunikasi yang termasuk dalam faktor pribadi yang dapat mempengaruhi seseorang dalam mengambil keputusan. Komunikasi disini juga komunikasi yang berhubungan interaksi langsung dengan orang lain yang mempengaruhi keputusan membayar zakat melalui lembaga zakat, sehingga orang yang membayar zakat melalui lembaga zakat menyukai komunikasi secara langsung.

Keluarga merupakan organisasi kecil yang penting dalam mempengaruhi anggotanya yang bersumber dari orang tua, suami atau istri, anak, saudara. Dalam penelitian ini keluarga memiliki peran dalam mengambil setiap keputusan sehingga dapat dilihat pribadi seseorang terhadap kedekatannya dengan keluarga. Sehingga dapat disimpulkan bahwa $75 \%$ dari responden yang memilih membayar zakat melalui lembaga merupakan responden yang selalu mendiskusikan setiap keputusanya bersama keluarga.

Dalam penelitian ini pengetahuan termasuk dalam faktor psikologi yang merupakan salah satu faktor yang mepengaruhi keputusan konsumen dalam membeli barang. Pengetahuan dalam hal ini adalah responden selalu mendapat informasi melalui televisi, artinya responden lebih menyukai mendapat informasi-informasi dari televisi, kemudian Informasi baru akan merubah keputusan responden artinya bahwa apabila responden mendapat informasi baru dapat merubah keputusan yang lama. Dapat disimpulkan bahwa responden yang membayar zakat melalui lembaga zakat adalah responden yang sering mendapat informasi melalui televisi dan orang yang dapat merubah keputusan lamanya ketika mendapat informasi baru yang diterima.

Kelompok acuan adalah orang atau kelompok orang yang mempengaruhi secara bermakna perilaku individu (Engel, Blackwell, 1994: 166). Dalam penelitian ini kelompok acuan termasuk dalam faktor pribadi meliputi kepercayaan diri ketika bersama teman-teman dan menyukai persaingan. Dapat diambil kesimpulan bahwa orang yang membayar zakat melalui lembaga zakat merupakan orang yang merasa percaya diri dengan kelompoknya, dan orang yang menyukai persaingan.

Motivasi adalah keadaan yang dapat mendorong seseorang dalam melakukan sesuatu untuk mencapai tujuan tertentu. Dalam penelitian ini motivasi dari 
responden adalah motivasi atas keinginannya dimasa depan membuat bersemangat dalam mengerjakan sesuatu artinya bahwa orang tersebut selalu melihat keuntungan dan manfaat dimasa depan sehingga ia bersemangat untuk mengerjakannya, sehingga orang yang membayar zakat melalui lembaga zakat adalah orang yang selalu melihat manfaatnya dimasa depan.

$\mathrm{F}_{2}=0,732$ interaksi $+0,678$ budaya mengajarkan $+0,574$ Prestasi $+0,568$ Pekerjaan

Interaksi adalah hubungan antara satu orang dengan yang lainnya, dalam penelitian ini $73,2 \%$ interaksi dapat menjadi faktor kedua yang dapat menjelaskan pada keputusan dalam membayar zakat melalui lembaga zakat. Interaksi disini adalah kemudahan seseorang dalam bersosialisasi dengan lingkungan baru dan selalu berinteraksi dengan orang banyak, orang yang mengambil keputusan membayar zakat melalui lembaga zakat adalah orang yang mudah bersosialisasi dengan lingkungan baru dan orang yang selalu berinterasksi dengan orang banyak.

Budaya dipelajari adalah alih-alih manusia belajar norma mereka melalui peniruan (imitation) atau dengan mengamati proses (Engel, Blackwell, 1994: 71). Dalam penelitian ini dijelaskan dengan pernyataan bahwa orang tersebut selalu menerapkan budaya tolong-menolong dilingkunganya dan orang tersebut selalu menerapkan nilai-nilai Islam dalam kehidupannya artinya pernyataan tersebut menggambarkan norma mereka terhadap budaya yang telah diterapkan dilingkungannya. Dari hasil kuisioner bahwa budaya $67,8 \%$ menyatakan bahwa orang yang membayar zakat melalui lembaga zakat selalu menerapkan budaya tolong-menolong dilingkungannya dan selalu menerapkan nilai-nilai Islam dalam kehidupannya.

Prestasi merupakan keunggulan yang dimiliki seseorang yang menggambarkan kelas sosial seseorang, dengan pernyataan dibutuhkan dimanapun menjelaskan bahwa orang tersebut selalu dibutuhkan oleh lingkungannya dimanapun berada. Sehingga faktor kedua yang menjadi penentu orang membayar zakat melalui lembaga zakat adalah orang yang selalu dibutuhkan oleh lingkungannya dimanapun berada dan berada dikelas sosial yang cukup tinggi.

Pekerjaan merupakan salah satu faktor kedua yang mempengaruhi gaya hidup seseorang sehingga dapat mempengaruhi keputusan dan dapat meggambarkan kelas sosial seseorang dengan pernyataan dalam kuisioner berikut, ditempatkan pada posisi yang tinggi dalam pekerjaan, menyukai profesi kerja saat ini. $56,8 \%$ responden menyatakan bahwa pekerjaan mempengaruhi keputusan membayar zakat. Sehingga orang yang membayar zakat melalui lembaga adalah orang yang memiliki posisi pekerjaan kerja tinggi, dan orang yang menyukai pekerjaanya.

$\mathrm{F}_{3}=0,534$ Gaya hidup

Gaya hidup merupakan pola hidup yang dimiliki seseorang sehingga berdampak pada keseharian individu tersebut, gaya hidup mempengaruhi cara membayar zakat melalui lembaga zakat, faktor ini memiliki nilai 0,534 atau $53,4 \%$ dengan pernyataan bahwa pergi keluarkota untuk berlibur, sehingga dapat digambarkan bahwa orang yang membayar zakat melalui lembaga zakat merupakan orang yang cenderung memperhatikan gaya hidupnya karena orang tersebut sering melihat informasi diberbagai daerah yang dikunjungi karena dia sering pergi keluar kota untuk berlibur dengan posisi dalam faktor ketiga yang mempengaruhi keputusan membayar zakat melalui lembaga zakat.

$\mathrm{F}_{4}=0,761$ Budaya Ditanamkan

Yang menjadi faktor keempat yang mempengaruhi keputusan dalam membayar zakat melalui lembaga zakat adalah budaya ditanamkan artinya budaya diteruskan dari satu generasi kegenerasi lainnya. (Engel, Blackwell, 1994: 72). 
Sehingga pernyataaan dalam kuisioner adalah mementingkan hukum adat maksudnya adalah orang tersebut selalu mementingkan hukum adat atau hukum lain yang berlaku dilingkungannya karena meneruskan budaya dari generasi terdahulu. Sehingga orang yang mengambil keputusan membayar zakat melalui lembaga adalah orang yang selalu mementingkan budaya atau hukum yang berlaku dilingkungannya.

$\mathrm{F}_{5}=0,846$ Budaya Menyesuaikan

Faktor kelima adalah Budaya bersifat menyesuaikan yaitu suatu wujud yang melayani manusia didalam upaya memenuhi kebutuhan biologis dan sosial dasar dari masyarakat (Engel, Blackwell, 1994: 72). Sehingga pernyataan dalam kuisioner untuk menggambarkan budaya bersifat menyesuaikan terhadap kebutuhan biologis dan sosial seseorang adalah menghormati orang yang lebih tua, menyukai bahasa sopan dan santun dan mudah bergaul dan ramah. Orang yang mengambil keputusan membayar zakat melalui lembaga zakat adalah orang yang selalu menghormati yang lebih tua, menyukai kesopanan dan kesantunan. Dengan menempati posisi faktor yang kelima.

Analisis Faktor Muzakki yang Membayar melalui Non Lembaga Zakat

Analisis faktor non lembaga zakat dalam penelitian ini adalah untuk mengetahui faktor apa saja yang mempengaruhi preferensi masyarakat dalam nengambil keputusan membayar zakat melalui non lembaga zakat.

Angka Kaiser mayer Olkin Measure of Sampling Adequacy (KMO-MSA) sebesar 0,671 lembaga zakat dan 0,650 untuk non lembaga zakat, hasil ini termasuk pada hasil yang baik mengingat angka ini sudah diatas 0,5. Nilai Bartlett's Test of Sphericity mempunyai nilai 392.081 pada lembaga zakat dan 451.541 pada non lembaga zakat dengan nilai signifikasi 0,000. Nilai ini berarti bahwa faktor pembentuk variabel sudah cukup dan bisa dianalisis lebih.
Berdasarkan nilai komunalitas untuk variabel budaya mengajarkan, mempunyai nilai extraction tertinggi yaitu sebesar $0,81,6$. Hal ini berarti $81,6 \%$ varian variabel keyakinan akan terbentuk. Kemudian untuk variabel budaya ditanamkan $47,5 \%$, budaya mengajarkan 60,2\%, pekerjaan 58,4\%, interaksi $\quad 65,5 \%$, komunikasi $\quad 79,8 \%$ kepemilikan $65,4 \%$, gaya hidup $63,6 \%$ keluarga 64,7\%, kelompok acuan 66,9\%, pengetahuan 55,5\%, motivasi $73,3 \%$, keyaninan $75,7 \%$ dan variabel prestasi mempunyai nilai extraction terendah 0,378. Hal ini berarti $37,8 \%$ varian dari variabel prestasi dijelaskan oleh faktor yang akan terbentuk. Dan variabel semakin besar nilai communalities menunjukan semakin kuat hubungan dengan faktor yang nantinya akan terbentuk.

Selanjutnya berdasarkan pengolahan data SPSS 20.0 didapat hasil bahwa 14 variabel yang digunakan dalam penelitian ini akan dikelompokan dalam 5 faktor sebagai berikut:

a. Faktor pertama yang mempunyai eigenvalue sebesar $=3,652$, varian sebesar $26,084 \%$

b. Faktor kedua mempunyai nilai eigenvalue sebesar $=1.760$, varian sebesar $12,573 \%$

c. Faktor ketiga mempunyai nilai eigenvalue sebesar $=1.321$, varian sebesar $9,434 \%$

d. Faktor keempat mempunyai nilai eigenvalue sebesar $=1.149$, varian sebesar 8,209\%

e. Faktor kelima mempunyai nilai eigenvalue sebesar $=1.076$, varian sebesar $7,684 \%$

Hasil tersebut menunjukan bahwa faktor 1 mampu menjelaskan seluruh varian sebesar 26,084\%, faktor 2 menjelaskan seluruh varian sebesar $12,573 \%$, faktor 3 menjelaskan seluruh varian sebesar 9,434\%, faktor 4 menjelaskan seluruh varian sebesar 8,209\%, dan faktor 5 menjelaskan seluruh varian sebesar 7,684\%. Sedangkan berdasarkan kumulatif seluruh faktor dapat menjelaskan varian sebesar 63,983\% 
Analisis selanjutnya dilakukan pada component matrix yang menunjukan distribusi 14 variabel pada 5 faktor yang terbentuk. Angka-angka yang terdapat pada tabel component matrix merupakan factor of loading yang menunjukan besar kolerasi antara suatu variabel dengan faktor pertama, kedua, ketiga, keempat dan kelima. Proses penentu variabel asal kedalam faktor dilakukan dengan membandingkan besar kolerasi tiap baris yang didasarkan pada angka mutlak factor of loading yang diberikan setiap variabel terhadap masing-masing faktor.

Dalam Tabel component matrix ini, masih ada beberapa variabel yang tidak terlihat perbedaan nyata pada nilai loading factor, sehingga sulit untuk menentukan variabel tersebut termasuk faktor yang mana. Hal ini terlihat dari masih ada nilai loading factor yang di bawah 0,5 , yaitu pada variabel Gaya hidup. Padahal syarat suatu variabel masuk ke dalam suatu faktor, nilai loading factor harus di atas 0,5. Untuk melihat perbedaan yang nyata pada nilai loading factor dari setiap variabel, maka harus dilakukan proses rotasi. Rotasi dalam penelitian ini adalah rotasi dengan metode Varimax, yang bertujuan untuk memperbesar nilai loading factor yang dulunya memang sudah besar dan memperkecil nilai loading factor yang dulunya memang sudah kecil, sehingga diperoleh distribusi loading factor yang lebih jelas dan nyata.

Setelah dilakukan rotasi, maka dapat dengan mudah menentukan variabelvariabel mana yang akan masuk kelima faktor tersebut. Dari rotated komponen matrix kita melihat bahwa variabel yang termasuk dalam component 1 yaitu variabel komunikasi, keyakinan, pengetahuan, keluarga, dan motivasi. Dengan nilai factor of loading masing-masing variabel sebesar $0,846,0,803,0,695,0,668$, dan 0,512. hal ini berarti, bahwa variabel tersebut mempunyai kolerasi yang tinggi terhadap faktor 1, kemudian untuk component 2 yaitu variabel interaksi, dan motivasi dengan nilai factor of loading masing-masing variabel sebesar 0, 738 dan 0,654, kemudian untuk component 3 yaitu pekerjaan dengan nilai factor of loading sebesar 0,638, kemudian untuk component 4 yaitu budaya mengajarkan dengan nilai factor of loading sebesar 0,761 dan untuk component 5 yaitu budaya menyesuaikan dengan nilai factor of loading sebesar 0,846.

Hasil analisis faktor adalah 14 variabel yang diteliti melalui analisis faktor dengan metode ekstraksi principle component analysis yang direduksi menjadi 5 faktor dimana variabel-variabel komunikasi, keyakinan, pengetahuan, keluarga, dan motivasi yaitu faktor 1, interaksi, dan motivasi yaitu faktor 2, pekerjaan adalah faktor 3, budaya mengajarkan yaitu faktor 4, dan budaya menyesuaikan yaitu faktor 5 .

Faktor pertama didapatkan persamaan matematis sebagai berikut: $F_{1}=0,848$ Komunikasi, + 0,803 Keyakinan + 0,688 Pengetahuan + 0,695 Keluarga

Faktor pertama ini memiliki eigenvalue sebesar 3,844, sehingga dapat disimpulkan bahwa ini merupakan faktor yang paling mempengaruhi keputusan membayar zakat melalui lembaga zakat, faktor 1 ini dapat mempengaruhi keragaman data sebesar $27.084 \%$.

Komunikasi dalam penelitian ini adalah komunikasi yang termasuk dalam faktor pribadi yang dapat mempengaruhi seseorang dalam mengambil keputusan. Komunikasi disini juga komunikasi yang berhubungan interaksi langsung dengan orang lain tidak melalui perantara. Sehingga orang yang membayar zakat melalui non lembaga zakat menyukai komunikasi secara langsung tidak melalui perantara, jadi orang yang membayar zakat melalui non lembaga zakat adalah orang yang lebih menyukai pembayaran langsung tidak melalui perantara.

Keyakinan adalah keadaan dimana seseorng meyakini terhadap keputusan yang dipilih, dari hasil kuisioner memperlihatkan bahwa $80,3 \%$ responden mengambil keputusan atas dasar keyakinan, sehingga faktor ini merupakan faktor yang 
mempengaruhi pengambilan keputusan membayar zakat melalui non lembaga zakat. Hal ini dapat diartikan bahwa ada sekelompok muzakki yang membayar zakat melalui non lembaga zakat adalah orang yang meyakini bahwa membayar zakat secara langsung kepada mustahik berarti telah menyalurkan dana zakatnya dengan tepat.

Dalam penelitian ini pengetahuan termasuk dalam faktor psikologi yang merupakan salah satu faktor yang mepengaruhi keputusan konsumen dalam membeli barang. Pengetahuan dalam hal ini adalah responden selalu mendapat informasi melalui televisi, artinya responden lebih banyak mendapat informasi-informasi dari televisi, kemudian Informasi baru akan merubah keputusan responden artinya bahwa apabila responden mendapat informasi baru dapat merubah keputusan yang lama. sehingga responden yang membayar zakat melalui non lembaga zakat adalah responden yang sering mendapat informasi melalui televisi dan orang yang dapat merubah keputusan lamanya ketika mendapat informasi baru yang diterima.

Keluarga merupakan organisasi kecil yang penting dalam mempengaruhi anggotanya yang bersumber dari orang tua, suami atau istri, anak, saudara. Dalam penelitian ini keluarga memiliki peran dalam mengambil setiap keputusan sehingga dapat dilihat pribadi seseorang terhadap kedekatannya dengan keluarga. Sehingga dapat disimpulkan bahwa 69,5\% dari responden yang memilih membayar zakat melalui non lembaga merupakan responden yang selalu mendiskusikan setiap keputusanya bersama keluarga.

$\mathrm{F}_{2}=0,733$ interaksi $+0,654$ Motivasi $+0,574$

Prestasi

Interaksi adalah hubungan antara satu orang dengan yang lainnya, dalam penelitian ini 73,3\% intraksi dapat menjadi faktor kedua yang dapat menjelaskan pada keputusan dalam membayar zakat melalui non lembaga zakat. Interaksi disini adalah kemudahan seseorang dalam bersosialisasi dengan lingkungan baru dan selalu berinteraksi dengan orang banyak, orang yang mengambil keputusan membayar zakat melalui non lembaga zakat adalah orang yang mudah bersosialisasi dengan lingkungan baru dan orang yang selalu berinteraksi dengan orang banyak. Dalam variabel interaksi memiliki kesamaan posisi variabel dengan faktor kedua pada keputusan membayar zakat melalui lembaga yaitu pada faktor ke dua akan tetapi untuk melihat mana yang lebih berpengaruh, maka dapat dilihat dari nilai mean, keputusan membayar zakat melalui lembaga zakat memiliki nilai 1.7912 dan dan non lembaga zakat sebesar 1.8319 sehingga faktor kedua dengan variabel interaksi yang sangat berpengaruh adalah interaksi terhadap pembayaran zakat melalui non lembaga zakat.

Motivasi adalah keadaan yang dapat mendorong seseorang dalam melakukan sesuatu untuk mencapai tujuan tertentu. Dalam penelitian ini motivasi dari responden adalah motivasi atas keinginannya dimasa depan membuat bersemangat dalam mengerjakan sesuatu artinya bahwa orang tersebut selalu melihat keuntungan dan manfaat dimasa depan sehingga ia bersemangat untuk mengerjakannya, dapat diambil kesimpulan bahwa orang yang membayar zakat melalui non lembaga zakat adalah orang yang selalu melihat manfaat dimasa depan.

Prestasi merupakan keunggulan yang dimiliki seseorang yang menggambarkan kelas sosial seseorang, dengan pernyataan dibutuhkan dimanapun berada sehingga menjelaskan bahwa orang tersebut selalu dibutuhkan oleh lingkungannya dimanapun ia berada. Dapat diambil kesimpulan bahwa faktor kedua yang menjadi penentu orang membayar zakat melalui non lembaga zakat adalah orang yang selalu dibutuhkan oleh lingkungannya dimanapun berada atau berada dikelas sosial yang cukup tinggi. Dalam variabel prestasi memiliki kesamaan dengan keputusan membayar zakat melalui lembaga zakat yaitu pada faktor ke dua untuk melihat 
mana yang lebih berpengaruh, maka dapat dilihat dari nilai mean yaitu 2.1648 pada keputusan membayar zakat melalui lembaga zakat dan non lembaga zakat 2.4336 pada non lembaga zakat, kemudian faktor kedua dengan variabel prestasi yang sangat berpengaruh adalah terhadap pembayaran zakat melalui non lembaga zakat.

$F_{3}=0,638$ Pekerjaan

Pekerjaan merupakan faktor yang mempengaruhi gaya hidup seseorang sehingga dalam penelitan ini pekerjaan menjadi faktor ke tiga yang mempengaruhi keputusan dan dapat meggambarkan kelas sosial sesorang dengan pernyataan dalam kuisioner adalah ditempatkan pada posisi yang tinggi dalam pekerjaan, menyukai profesi kerja saat ini. 63,8\% responden menyatakan bahwa pekerjaan mempengaruhi keputusan membayar zakat. Sehingga orang yang membayar zakat melalui non lembaga adalah orang yang memiliki pada posisi tinggi dalam pekerjaan atau pemilik usaha, dan orang yang menyukai pekerjaanya.

$\mathrm{F}_{4}=0,761$ Budaya Mengajarkan

Yang menjadi faktor keempat yang mempengaruhi keputusan dalam membayar zakat melalui lembaga zakat adalah budaya mengajarkan artinya adalah budaya sebagai suatu wujud yang melayani manusia didalam upaya memenuhi kebutuhan biologis dan sosial dasar dari masyarakat. (Engel, at.,al, 1994: 72). Dalam penelitian ini dijelaskan dengan pernyataan bahwa orang tersebut selalu menerapkan budaya tolong-menolong dilingkunganya dan orang tersebut selalu menerapkan nilainilai Islam dalam kehidupannya artinya pernyataan tersebut menggambarkan norma mereka terhadap budaya yang telah diterapkan dilingkungannya. Dari hasil kuisioner budaya $76,1 \%$ responden orang yang membayar zakat melalui non lembaga zakat adalah orang selalu menerapkan budaya tolong-menolong dilingkungannya dan selalu menerapka nilai-nilai Islam dalam kehidupannya.

$F_{5}=0,846$ Budaya bersifat menyesuaikan
Faktor kelima adalah Budaya bersifat menyesuaikan adalah suatu wujud yang melayani manusia didalam upaya memenuhi kebutuhan biologis dan sosial dasar dari masyarakat (Engel, Blackwell, 1994:72). Sehingga pernyataan dalam kuisioner untuk menggambarkan budaya bersifat menyesuaikan terhadap kebutuhan biologis dan sosial seseorang adalah menghormati orang yang lebih tua, menyukai bahasa sopan dan santun dan mudah bergaul dan ramah. Orang yang mengambil keputusan membayar zakat melalui non lembaga zakat adalah orang yang selalu menghormati yang lebih tua, menyukai kesopanan dan kesantunan.

\section{KESIMPULAN DAN IMPLIKASI}

Berdasarkan penelitian yang telah dilakukan di Kabupaten Sukabumi, maka kesimpulan adalah sebagai berikut:

1. Karakteristik masyarakat Kabupaten Sukabumi yang membayar zakat melalui lembaga zakat dari 91 responden yaitu jumlah responden terbanyak adalah Cicurug, dengan jenis kelamin Pria rata-rata usia 31-40 tahun dengan status menikah memiliki jumlah anggota keluarga 4, jenis pekerjaan yang dimiliki Pegawai Negeri Sipil dengan tingkat pendidikan S1, rata-rata pendapatan $\mathrm{Rp} \quad 3.600 .000$ sampai dengan $\mathrm{Rp}$ 5.600.000, dengan tingkat pengeluaran $\mathrm{Rp} \quad 3.000 .000$ samapai dengan $\mathrm{Rp} 4.000 .000$. rata-rata membayar zakat profesi dengan kisaran pembayaran zakat perbulan sebesar Rp 100.000 sampai dengan Rp 200.000, muzakki yang membayar melalui lembaga zakat mendapat informasi zakat dari sosialisasi BAZNAS.

2. Karakteristik masyarakat Kabupaten Sukabumi yang membayar zakat melalui non lembaga zakat dari 113 responden yaitu jumlah responden terbanyak adalah Cicurug dengan jenis kelamin Pria, rata-rata usia 31-40 tahun dengan status menikah memiliki jumlah anggota keluarga 4, memiliki jenis pekerjaan pedagang dengan tingkat pendidikan 
SMA/Sederajat yang memiliki rata-rata pendapatan $\mathrm{Rp}$ 3.600.000 sampai dengan Rp 5.600.000, dangan tingkat pengeluaran $\mathrm{Rp} \quad 1.000 .000$ sampai dengan $\mathrm{Rp}$ 2.000.000. zakat yang dibayar zakat prdagangan dengan kisaran pembayaran zakat perbulan sebesar Rp 100.000 sampai dengan Rp 200.000.

3. Dari hasil analisis data yang dilakukan dapat diketahui bahwa faktor yang mempengaruhi keputusan membayar zakat melalui lembaga zakat adalah faktor pertama adalah faktor psikologi dan faktor sosial, terdiri dari keyakinan, komunikasi, keluarga, pengetahuan, kelompok acuan motivasi. Faktor kedua adalah Faktor sosial meliputi interaksi, pekerjaan dan prestasi. Faktor ketiga adalah faktor sosial yaitu gaya hidup, faktor keempat adalah faktor budaya yaitu budaya ditanamkan, faktor kelima adalah budaya yaitu budaya menyesuaikan.

Faktor yang mempengaruhi keputusan membayar zakat melalui non lembaga zakat adalah faktor pertama adalah faktor pribadi dan faktor sosial terdiri dari komunikasi, keyakinan, keluarga, pengetahuan Faktor kedua adalah Faktor sosial dan faktor psikologi meliputi interaksi dan motivasi. Faktor ketiga adalah faktor sosial yaitu pekerjaan, faktor keempat adalah faktor budaya yaitu budaya memngajarkan, faktor kelima adalah budaya yaitu budaya menyesuaikan.

Implikasi dari penelitian ini antara lain:

1. Mengingat Kabupaten Sukabumi yang memiliki potensi cukup besar terhadap pengumpulan dana zakat dengan tingkat penerimaan lembaga masih rendah maka lembaga zakat di Kabupaten Sukabumi harus terus giat dalam melakukan sosialisasi secara menyeluruh, dan membangun kepercayaan pada masyarakat kabupaten Sukabumi.

2. Strategi penghimpunan dana zakat sebaiknya memperhatikan karakteristik masyarakat dilingkungan, sehingga lembaga zakat akan lebih mudah untuk melakukan sosialisasi maupun penyuluhan kepada masyarakat mengenai zakat berdasarkan karakterkarakter yang dimiliki masyarakat.

\section{DAFTAR PUSTAKA}

Achmad, Andy Faisal. 2012. Analisis Pengaruh Faktor Budaya, Sosial, Pribadi Dan Psikologis Terhadap Keputusan Pembelian Semen Gresik Di Semarang. Fakultas Ekonomika Dan Bisnis Universitas Diponegoro Semarang.

Ali, Mohammad, Mohammad Ansor. 2014. Psikologi Remaja. Jakarta: Bumi Akasara.

Arianty, Dewi, Yana Rohmana. 2012. FaktorFaktor Yang Mempengaruhi Preferensi Konsumen Provider Indosat Di Perguruan Tinggi Negeri Kota Bandung.

Arief, Anandita. 2010. Peran Laporan Keuangan Dan Intusin Dalam Pengambilan Keputusan Kredit (Studi Empiris Pada Perbankan Kota Semarang) Fakultas Ekonomi. Universitas Diponegoro Semarang.

Bachmid, Gamsir. 2012. Perilaku Muzakki Dalam Membayar Zakat Mal (Studi Fenomenologi Pengalaman Muzakki Di Kota Kedari). Jurnal Aplikasi Manajemen | Volume 10 | Nomor 2 | Juni 2012.

Engel, James. dkk 1994. Perilaku Konsumen. Jakarta : Binarupa Aksara.

Faisal. 2011. Sejarah Pengelolaan Zaakat Di Dunia Muslim dan Indonesia (Pendekatan Teori InvestigasiSejarah Charles dan Defisit Kebenaran Lieven Boeve. Jurnal Analisis Volume XI, Nomor 2, Desember 2011 
Fauza, Yaumil. 2013. Preferensi Masyarakat Dalam Memilih Institusi Pembayaran Zakat Di Kota Medan. Universitas Sumatera Utara.

Gayatri, Dwi. 2004. Jurnal Keperawatan Indonesia, Volume 8, No. 2, September 2004; 76-80.

Ghoni, Abdul, Tri Bodroastuti. 2010. Pengaruh Faktor Budaya, Sosial, Pribadi Dan Psikologi Terhadap Perilaku Konsumen (Studi Pada Pembelian Rumah Di Perumahan Griya Utama Banjardowo Semarang). Sekolah Tinggi Ilmu Ekonomi Widya Manggala.

Herawati, Lisna Nety. 2012. Preferensi Dan Keputusan Masyarakat Karawaci Dalam Membaar Zakat. Program Studi Muamalat (Ekonomi Islam), Universitas Islam Syarif Hidayatullah.

Huda, Nurul. Mohammad Heykal. 2013. Lembaga Keungan Islam Tinjauan Teoritis Dan Praktis. Jakarta: Kencana.

Junaidi, Manal. 2006, Analisis Dan Evaluasi Faktor Yang Mempengaruhi Perilaku Pembelian Franchise (Waralaba) (Studi Kasus Alfamart Wilayah Jabotabek). Departemen Manajemen Fakultas Ekonomi Manajemen. Institut Pertanian Bogor.

Kanji, Lusiana, H. Abd. Hamid Habbe Dan Mediaty. 2011. Aktor Determinan Motivasi Membayar Zakat Determinant Factors Motivation Paying Zakat Zakat And Magnitude Of Value.

Karli, Hilda. 2013. Pertimbangan Dan Stategi Pengambilan Keputusan Kepala Sekolah, Jurnal Pendidikan Penabur No.21/Tahun Ke12/Desember.
Kountour, Ronny. 2003. Metode Penelitian Untuk Menulis Skripsi Dan Tesis, Jakarta: PPM.

Mardani. 2011 Hukum Ekonomi Syariah di Indonesia. Bandung: Refika Aditama.

Maryati, Sri. 2009. Faktor-Faktor Yang mempengaruhi Preferensi Masyarakat Dalam Memilih Sekolah Menengah Kejuruan Negeri (SMKN) Di Kota Semarang, Tesis pada Program Pascasarjana Magister Teknik Pembangunan Wilayah Dan Kota Universitas Diponegoro Semarang.

Mashudi. 2011. Evalusi Pengelolaan Zakat di Inodesia

Nasution, Edwin Mustafa, Hardius Usman. 2007. Proses Penelitian Kuantitatif, Jakarta: FEUI.

Nurdin. 2011. Pengaruh Pengelola Zakat Terhadap Kesejahteraan Rakyat, Program Akutansi Fakultas Ekonomi Universitas Widyatama.

Pratama, Erwin Aditya. 2013. Optimalisasi Pengelolaan Zakat Sebagai Sarana Mencapai Kesejahtaraan Sosial (Studi dibidang Amil Zakat Kota Semarang). Fakultas Hukum. Universitas Negri Semarang.

Qardawi, Yusuf. 2011. Hukum Zakat. Bogor: Pustaka Litera Antara.

Runtuwene, Lastiko. 2007. Kepemimpinan Dan Pengambilan Keputusan Partisipatif Dalam Organisasi Pendidikan-Sekolah, Jurnal Pendidikan Penabur.

Siska, Hanna. 2012. Analisi Preferensi Muslim Jakarta Dalam Membayar Zakat Penghasilan (Uji Model Partial Least Square) Dan Potensi 
Adanya Perhitungan Dobel Zakat. Skripsi Pada Program Studi Ekstensi. Universitas Indonesia.

Sukma, Ating. 2013. Keterkaitan Faktor Sosial Ekonomi Yang Mempengaruhi Penerapan Zakat Di Indonesia Dengan Pendekatan Tawhidi. Ringkasan Disertasi. Program Doktor Ilmu Ekonomi. Universitas Trisakti.

Taufiq, Ahmad. 2014. Analisis Kinerja Pelayanan BAZNAS Kabupaten
Sukabumi terhadap Tingkat Kepuasan Muzakki. skripsi pada Program Studi Ekonomi Islam Universitas Djuanda Bogor.

Wijayanti. Putri Sekar. 2011. Hubungan Tingkat Pengetahuan Dan Pekerjaan Ibu Dengan Pemberian Asi Eksklusif Pada Bayi 6-12 Bulan Di Desa Margorejo Kec. Margorejo Kab. Pati, Universitas Muhammadiyah. 